Muséologies

Les cahiers d'études supérieures

muséologies

\title{
The contemporary art museum as a time-space for the participatory creation and production of complex works of art: Some examples from the italian scene
}

\section{Alessandra Piatti}

Volume 8, numéro 1, 2015

Réflexions sur la pratique curatoriale et la recherche-création

URI : https://id.erudit.org/iderudit/1034613ar

DOI : https://doi.org/10.7202/1034613ar

Aller au sommaire du numéro

Éditeur(s)

Association Québécoise de Promotion des Recherches Étudiantes en

Muséologie (AQPREM)

ISSN

1718-5181 (imprimé)

1929-7815 (numérique)

Découvrir la revue

Citer cet article

Piatti, A. (2015). The contemporary art museum as a time-space for the participatory creation and production of complex works of art: Some examples from the italian scene. Muséologies, 8(1), 115-129.

https://doi.org/10.7202/1034613ar

Tous droits réservés (C Association Québécoise de Promotion des Recherches Étudiantes en Muséologie (AQPREM), 2016
Ce document est protégé par la loi sur le droit d'auteur. L'utilisation des services d'Érudit (y compris la reproduction) est assujettie à sa politique d'utilisation que vous pouvez consulter en ligne.

https://apropos.erudit.org/fr/usagers/politique-dutilisation/ 
Article cinq

The contemporary art museum as a time-space for the participatory creation and production of complex works of art: some examples from the italian scene

Alessandra Piatti 
The author holds a bachelor's degree in Conservation of Cultural Heritage from the Genoa University. In the same University she earned a master's degree in Art History and Valorization of Artistic Heritage in 2010. In 2008 she founded the Ko.Ji.Ku. Association, a cultural association engaged in curatorial activity of exhibitions and cultural events. From 2012 to the present she has contributed to the Juliet Art Magazine and collaborated with AdAC-Archive of Contemporary Art at Genoa University, completing several research projects in conservation, museological and contemporary art historical fields. In April 2014 she completed her Ph.D. fellowship in Visual Arts, Performing Arts and Multimedia Technologies. She is also a Teaching Assistant in Methodologies for the Contemporary Art Study and in History of Contemporary Sculpture at Genoa University and a member of INCCA (International Network for the Conservation of Contemporary Art) Network. 


\section{Introduction}

Interest in investigating contemporary works of art directly in museum spaces, above all at the time of exhibition, has grown considerably since the early 2000's. From Julie Reiss's contribution ${ }^{1}$, that argued the new close relationship between museum activity and installation art, and from Nicolas Bourriaud's essay $^{2}$, that highlighted the relation between relational art and museum, the number of critical studies focused on the analysis of the contemporary artwork in the museum context has increased ${ }^{3}$. This phenomenon derives from the 1980s when many artists changed their attitudes towards museums spaces thanks to the diffusion of installation practices within the museum context ${ }^{4}$. This practice drove artists to no longer consider museums as places in which their works are mummified, but as spaces to experiment with, places in which to present not only the end result of their research but also the conceptual procedure behind it. In addition, now artists have recognised the inexhaustible source of creativity that develops from constantly relating with other figures in the museum, such as visitors and staff, leading contemporary museums to expose and document the creative process as well as provide the space/time it is acted out in.

As Claire Bishop writes ${ }^{5}$, if the progressive broadening of the sphere of authorship became more visible from the end of the 1960's onwards the moment artists began using media to dialogue with other figures (technicians, producers, curators, other artists, intellectuals, participants and the public), it is only more recently that contemporary criticism has begun to reflect on this type of participation and the types of co-authorship that exist within the process of artistic research/creation, which are widely recognised in other spheres, such as theatre, music and cinema. The consequent similarities of contemporary works of art, in terms of multiple authorship, to theatrical, musical or cinematographic works, have been studied not only as theoretical speculation, but above all to identify the mechanisms that lie behind the creation and production of the work, and to work out new approaches to intervention and methodologies for the care, exhibition, documentation and conservation of works housed in museums. The spread of "behind the scenes" glimpses of artists' creative processes, as well as museum display and management practices, is of ever increasing interest to scholars and museums. The reasons for this are rooted on the one hand in the deconstructionist approach adopted by theoretical research-which has strongly influenced both research/creation, as well as the methods used to curate works that derive from it - and on the other hand in a sociological and anthropological interest in the system of relationships generated around the creation and production of contemporary $\mathrm{art}^{6}$.

Exhibitions dedicated to "behind the scenes" looks at the creative process and museum display and management processes are a useful tool for:

- attracting the interest of a general public interested in "spying" on museums, in understanding mechanisms that are usually kept secret;

- illustrating all the steps involved in the artistic operation, simplifying a complex
1 REISS, Julie H. From Margin to Center: The Spaces of Installation Art. Cambridge: MIT Press, 1999.

2 BOURRIAUD, Nicolas. Estétique Rélationelle, Paris: Presses du réel, 1998.

3 For the analysis of this relationship between museum and works of art from a conservative, museological and theoretical perspective, I refer here also to: YANEVA, Albena. "When a bus met a museum: following artists, curators and workers in art installation", Museum and Society. vol. 1, no. 3, 2003, pp. 116-131; IRVIN, Sherri. "Museums and the Shaping of Contemporary Artworks". Museum Management and Curatorship. vol. 21, no. 2, 2006, pp. 143-156; SAAZE,
Vivian van. Installation Art and the Museum. Presentation and Conservation of Changing Artworks. Amsterdam: Amsterdam University Press, 2013.

4 Cf. BISHOP, Claire. Installation Art: A Critical History. London: Tate Publisher, 2005; COULTER-SMITH, Graham. Deconstructing Installation art. 'www.installationart.net/' (retrieved in September 2014).

5 BISHOP, Claire. Artificial Hells. Participatory Art and the Politics of Spectatorship. London: Verso, 2012, pp. 8-9.

6 Cf. BECKER, Howard, Les Mondes de l'art. Paris: Flammarion, 1988. 
reality comprised of multiple relationships and operations set into motion by museum staff and visitors.

Museologist Peter Van Mensch runs the museum in line with the changes of the contemporary age of social networks, as a participatory institution defined by platforms, forms of participation and a community of connected users ${ }^{7}$. According to Mensch, participatory paradigms shouldn't only affect the frontstage of the museum in the form of presentation, education and events, but also the backstage, i.e. the collection and the processes of display, documentation, conservation and restoration. The large number of exhibitions and educational projects based on participation between the museum and the public presenting the backstage of the museum machine organised recently, confirm the existence of a great deal of interest in the museum's inner workings on the part of the public ${ }^{8}$. Launched above all by museum conservation departments, who are most urgently interested in finding methods to approach the installation, re-installation and documentation of complex works of art, these initiatives reflect a trend towards deconstruction, detail, fragmentation and specialisation, which reflects the contemporary world and can be found in all sections of society, from finance to the art world. This phenomenon gives rise to the need to collaborate and delegate certain stages of the creative and production processes to others, in particular when it comes to pedagogical, participatory or performance works. The pedagogical, research and documentary nature of many artistic projects is also reflected in the museum, which is being transformed into a device for research, learning and education ${ }^{9}$.
Mine is an invitation to interpret the museum as a place for experimenting with and creating contemporary art, as well as a pedagogical/ educational tool, by presenting the results of a study carried out in several contemporary art museums in Italy: the Castello di Rivoli Contemporary Art Museum and the Museum of Modern Art in Bologna (MAMbo). Two museums with different characteristics and traditions, both in terms of the nature and history of their collections and foundation dates, as well as in terms of their approaches to didactics, communication and organisation: two systems with different configurations reflecting the ethical, theoretical and practical problems connected with the mediation, exhibition, documentation and conservation of museum collections. The investigation was carried out in close collaboration with museum staff, in particular with the departments responsible for looking after, documenting and cataloguing the collections. Using a method that combines an ethnographic approach (interviews, observation in situ and the collection itself, reordering and processing documents and information) and a deconstructionist approach (investigating the dynamics artistic work activates in the museum machine), I have been able to examine several case studies, which are emblematic from a re-installation and documentary point of view, and which affect the numerous aspects we have just mentioned, bringing into play different approaches to research/creation and, consequently, its presentation to the public:

1- the exhibition methods applied for a site specific installation, Mutterseelenallein by Reinhard Mucha, belonging to the permanent collection of the Castello di Rivoli, which contains within its own composition the method for mediating and documenting itself as well as the traces of its exhibition

8 See the following exhibition: Inside Installations, at the Stedelijk Museum voor Aktuele Kunst (2010), Mapping the studio at the Tate Modern (2010); MAXXI Installazioni. Cinque opere dalla collezione del MAXXI (2007) at MAXXI Museum in Rome; Regali e regole. Prendere, dare, sbirciare nel museo (2006) at MAMbo Museum in Bologna.

9 BISHOP, op. cit., pp. 241-242.
7 MENSCH, Peter van. A Work of Art in a Museum is a Work of Art in a Museum. Lecture at International Symposium Contemporary Art: Who Cares? Amsterdam: 9-11 June 2010. See also: MENSCH, Léontine Meijer-van, TIETMEYER, Elisabeth. Participative Strategies in Collecting the Present. Berlin: Panorama Verlag, 2013. 
past: the museum becomes an assistant to the artist's work, an invisible presence, allowing the work to develop, be communicated and used.

2- the presentation, management and documentation of participatory, pedagogical and relational works with elements of "delegated" performance ${ }^{10}$ as part of temporary exhibitions hosted and promoted by the MAMbo in Bologna. Disponibilità della cosa and Time capsule are works in which the creative process goes hand in hand with the process of production, which involves the participation of other figures. This broadens the concept of authorship and redefines and reflects on the role of the museum as an activator and guarantor of relational processes.

What approaches do these museums use to present the products of the research/creation process? How much does the level of the artist's participation in the exhibition vary? To what extent is the work the fruit of the system of relationships it activates within the museum? How much does the choice of exhibition projects and works to be presented influence the museum system and vice versa? To what extent does the collaborative aspect of the management practices reflect that of the artist's research-creation?

The boundaries between the frontstage and backstage become confused the moment installations are involved, i.e. works that undergo a continuous process of transformation due to the fact they are re-installed many times. This is confirmed by the fact that most studies carried out during the last decade analyse management practices relating to installation art or the relationship between curator and conservator as figures that accompany the artist during their creative/production process respectively ${ }^{11}$.

10 With the term "delegated" performance, Claire Bishop refers to the artistic tendency in which everyday people, "non- professionals or specialists in other fields", "are hired to perform on behalf of the artist", following his instructions. For the complete dissertation about this tendency, see the chapter Delegated Performance: Outsourcing Authenticity, in BISHOP, op. cit., pp. 219-240.
My aim is to expand these relationships to encompass a broader range of works, including relational and participatory art, which also reflect changes in contemporary museum practices.

\section{The museum as an exhibition space for the collective creation of complex artworks}

Most works of art displayed in museums are complex, variable and relational hybrids. They are activators of research, thought, experience, creativity, narration, sensations and mechanisms associated with memory and gnoseology, relations and connections. The definition of a "complex artwork" provides a clear outline of the problems to be tackled on an ethical, aesthetic, theoretical and practical level when it comes to a work of contemporary art. The complexity that characterises the work is reflected in the theoretical and practical complexity of the research-creation it originated from (from the conceptual/theoretical process of creation to the processes of production, installation and re-installation, and of dialogue and interaction with the public). It also reflects, to equal extent, the system of art-production/ art-fruition.

The complexity of these artworks' composition-more precisely, the complexity of the practices that generate them-require the production, storage, accessibility, and interoperability of contextual information on the works' cultural history (that implies the history of the transmission of the artwork and its documentary corollary), the "textual" and "contextual" reconstruction of the artistic intention (see Eco, 1990), as well as its reception modes" ${ }^{12}$.

Even though the above is mostly applied to installations or generative and technological works of art, it can nevertheless be applied

11 YANEVA, op. cit.; IRVIN, op.cit.; SAAZE, op. cit. 12 Cf. SABA, Cosetta G. Introduction. In NOORDERGRAAF, Julia, et al. Preserving and exhibiting Media Art. Challenges and Perspectives. Amsterdam: Amsterdam University Press, 2013, p. 98. 
to any type of project containing multiple material, technological, immaterial components, concepts and relations, which only when combined find meaning and artistic value. The theoretical complexity of these works derives from characteristics that define the contemporary creative process, i.e: a different conception of space, time and space-time; sophisticated use of digital media and technologies (in terms of conception, production and presentation); the use of concepts rooted in science and the humanities that aspire to find new perspectives and keys to interpreting society, humanity and the universe, with an educational, speculative, or documentary intent.

Complex contemporary works of art assume, more often than not, the identity of the research creative process. Slipping halfway between theoretical and applied research, the artist drives this process, often with the help of a team of collaborators belonging to different fields of study. The relationship between work-context-actors therefore creates a clear ods and museum practices and leads us to reflect on the work-system theorised by Jack Burnham $^{13}$, the Theory of Complex Systems ${ }^{14}$ and the Actor-Network-Theory ${ }^{15}$.

Due to their dynamic, multiple and variable configurations, complex works of art are often studied using the Theory of Complex Dynamic Systems. This theory can explain the link between artistic practice and aesthetic experience, which find a common frame of reference within it. The artwork therefore becomes a system that already contains the fruit of the exchange between agent and context, allowing both artists and the public to relate to each other and interpret and benefit from the work on a common level. Continuing this line of thought, a complex artwork encompasses not only the space but also the context of the

13 BURNHAM, Jack. "Systems Esthetics". Artforum. vol. 7, no. 1 , September 1968.

14 BRINCK, Ingar. "Situated Cognition, Dynamic Systems, and Art: On Artistic Creativity and Aesthetic Experience". Janus Head: Journal of Interdisciplinary Studies in Literature, Continental Philosophy, Phenomenological Psychology, and the Arts. vol. 9, no. 2, 2007, pp. 407-431.

museum, creating a sort of preferential route for the public. It shares not only a performative, variable, immanent and relational aspect, but also has a multiple character, or as defined by the scholar Vivian van Saaze, a multiple body ${ }^{16}$. The work no longer corresponds with an object, which even though it can be viewed from multiple perspectives, remains single, but rather with a system that is multiple by nature, in which the agents, i.e. the actors of the artistic operation (artists, co-creators, museum staff, curators, the public) are involved. Its identity is dependent on the observer and on the practices and actions that have produced and presented it each time.

In many instances the artist's research comes to life and assumes its own value only when exhibited or performed in a determined space/ time, today more than ever associated with the museum. Looking at museums, studying the system behind them, observing which strategies, approaches and methodologies they employ in relation to complex works of art, can help us understand how contemporary creation and production works. The life of museums is reflected in the works and vice versa; the museum seeks to renew its structure in order to house, use and preserve works that find their identity at the moment of exhibition, relation and execution. Studying display strategies allows us to glimpse the museum structure, which rests on the decisions taken by figures with different relational skills. Only the observation and documentation of these combined actions give the work back its identity as a collective action within the space and time defined by the museum. The collective aspect of artistic production, a fundamental key to understanding these works, has recently become the subject of much criticism and literature on museum studies, installation and relational art. This is thanks to an approach rooted in sociology and in the Actor-Network-Theory

15 LATOUR, Bruno. Reassembling the social. An introduction to Actor-Network-Theory. Oxford: Oxford University Press, 2005. 16 SAAZE, op.cit., pp. 80-83. 
in particular. Developed by Bruno Latour and Michel Callon with the aim of understanding how processes connected with the technological innovation, production methods and scientific knowledge of our times, it is articulated through a network of relationships ${ }^{17}$. The Actor-Network-Theory involves the analysis of a collection of negotiations that describes the progressive creation of a network in which 'human' and 'non-human' actors assume identities in accordance with prevalent strategies for interaction. The most important form of negotiation for the French authors is 'translation', a multiple interaction in which actors construct common definitions and meanings and cooperate in order to reach individual and collective goals. In Actor-Network-Theory both actors and agents - - beings or things that participate in the process-share the scene during the production of the network of interactions that leads to the stabilisation of the system. Applying this approach to contemporary museum practice, in which the conservation, display and documentation of works is above all a process of negotiation, we come to consider, in agreement with Albena Yaneva ${ }^{18}$ and Vivian Van Saaze ${ }^{19}$, complex works of art within museum spaces as being agents with the power to act the moment they are incorporated with scripts to be followed by all actors involved in the collective production and re-creation of the work. These texts create a relationship between what is written (by the planner) and the instructions (for the user), and instigate a distribution of skills amongst several actors. It so becomes possible to make a deeper investigation into which actors and agents are involved in the relationships that make up installation, performance and relational complex works of art within museums. There are those between staff and artist, and those between artist and specialists in the fields the artistic operation is investigating.
The need to reconsider all actors in the system, their connections, networks and associations, has the direct consequence of progressively expanding the concept of the artist/subject's intentionality. The latter then becomes the director, the actor that puts the agents into action in a museum that is seen as a laboratory, a place of actions, limitations, permissions, conditions, spatial requirements, security procedures, ordinary and extraordinary operations and conceptual, material and didactical interventions.

\section{Complex and participatory artworks in Italian museums}

Comparing artistic operations presented in different museums gives us an overview of different approaches towards exhibiting documentation, interaction and participation methods, giving us a broader, more variable and dynamic point of view.

The Castello di Rivoli, the first art museum in Italy entirely dedicated to contemporary art, has shown a preference for large installations of an environmental nature modelled especially for the museum spaces ever since it was opened in 1984. The curatorial line behind the museum's decision-making strategy and artistic direction follows precise criteria: the decision to acquire works built especially for the rooms of this historic residence, and the will to constantly renew the collection with works representing the Italian and international contemporary art scene, working in close dialogue with artists.

The museum's organisational structure is split between the curatorial department-comprised of several curators involved either with curating exhibitions or with the technical management of the collection - and the educational department. In addition to coordinating exhibitions on a technical level, the curatorial department also works in close contact with artists during the creation of the works. 
Helped by a group of display technicians and a restorer, the department gathers all the documentation connected with the works and enters it into the collection management system. It also coordinates all the handling, display, and regular as well as extraordinary maintenance of the works. The conservation (regular and extraordinary maintenance and restoration) is entrusted to an external restorer, who alternates with the group of display technicians in charge of the display, handling and regular maintenance of large installations and the replacement and conservation of technological and technical material. The concerted nature of these three figures (curator, installer, restorer/conservator), which together make up the museum's organisational, conservation and documentation departments, becomes a way of optimising effort and ensuring the quality of interventions carried out on the works for the purposes of re-installation and conservation. It is also an excellent approach for managing the museum's collection of installation art.

At the Castello di Rivoli the practice of operating in close contact with artists lies at the very heart of its conservation and exhibition practice, of its backstage and of its very identity. The installed work of art becomes the result of a network of relationships created between the curator, conservator, restorer, installer and the artist's intentionality, which is the core of the process.

Complex installation as a reflection of museum and exhibition practice is also at the heart Mutterseelenallein by Reinhard Mucha (19891991-2009). This work occupies an entire room in the Castello and is nourished by subsequent re-installations, bringing with it both physical traces of the spaces it has been installed in as well as documentation of its past, while also revealing museum mechanisms activated by its installation. In addition to summarising its own history and that of the spaces it has related with, Mutterseelenallein also reflects the specifics of Mucha's working practice and conceptual methods. It is an expression of his slow, meticulous and conceptual working method, and also of his dispute with the institutional world of the art museum. The sixteen large windows that comprise the work create a sort of museum within a museum: powerful and enduring, they contain small black and white photographs of empty chairseach one different from the next-for museum custodians and visitors, photographed by the artist, from different viewpoints, during the annual exhibition of local artists from his birthplace, Düsseldorf (at the Kunstpalast Ehrenhof) in 1979. The installation is opened and closed by a frame containing a black and white photograph of the Kunstpalast with the banner of the 1979 exhibition and a description of the work in Italian and German. The piece was conceived by Reinhard Mucha in 1989 as part of his first solo exhibition in Italy at the Galleria Lia Rumma in Naples. Starting from this initial core, over time the piece has grown to contain new components, creating a time bridge between 1979, 1989, 1991 and 2008. In 1991 Mutterseelenallein was re-installed at the Museum für Moderne Kunst (MMK) in Frankfurt. The material components of the installation remained inescapable and characterising components, whilst the artist began a new conceptual and material journey to adapt the work to the new space now housing it. The construction process and carefully selected materials activated a new process of production of the wall surface, onto which all the elements are hung, reconstructing a sort of background perfectly reproducing the floor of the museum. The same production machine was reactivated in 2007-once again involving the technical manager of the collection, the curator, the museum director, the artist and his assistant-when the Fondazione CRT Progetto Arte Moderna e Contemporanea acquired the piece and decided to house it permanently at the Castello di Rivoli. As with the display at the MMK, Mucha decided to build a wall to match the floor of the room it was installed in, in this case a pink granular stone. He also decided that the oak parquet panels made for the German museum shouldn't be destroyed. Now an integral part of the installation, they were exhibited in several piles filling the central space in the 
room. The empty space that characterised the room in Frankfurt was therefore now filled by piles of memory, such as in a Merzbau ${ }^{20}$, in this case however with a linear, precise, cold and geometrical character. The operation not only penetrated the museum's space but also its history, in particular the history of its construction. Room 19 is one of the few rooms that lost all trace of the original Savoy residence and was completely remodelled during the restoration process. Both in Frankfurt and Rivoli, Mucha has not only adapted the work to the space destined to house it, but has also sanctioned and initiated the exhibition and musealisation process. According to the technical manager for the collection, during the-verbal-negotiation stage between the curator, museum and artist, the latter drew up a sort of 'pact of trust' to ensure his work would remain on permanent exhibition at the museum. An exhibition and documentary process transformed into a musealisation process, which then becomes part of the work itself: this piece in fact aims to 'enter into the flooring structure' of the museum, challenging the museum system based on the ephemeral and on the logic of consumption. Adopting the same exhibition procedures as the museum in the production of his work, and making it a part of the architectural structure of the same by recreating its floor as a support for the windows, Mucha's work claims a fixed place within the institution as if the museum had not replaced and put an end to the role of the pre-revolutionary noble residence or monastery to become a home for works of $a r t^{21}$. Mucha's example is emblematic of how not only literature but also museum practices themselves, helped by the works created by them, are being oriented towards a

20 The Merzbau (1923-1936)—conventionally considered one of the precursors of the environment and installation art-was a growing installation, a living sculpture constructed by Kurt Schwitters assembling in his home-atelier some objects, images, texts and memories he collected in his everyday life. Thus, for the first time, a specific space becomes an autonomous work of art. type of musealisation that is forced to escape formalisation in exchange for variability and dynamism. As is taking place at the Castello di Rivoli, this process is continuously updated, being nourished by relationships and the museum practices of production, display and documentation.

The second example of this relational system considers two complex, relational and participatory works that the Museum of Modern Art in Bologna displayed as part of temporary exhibitions: Time capsule by Ryan Gander and Disponibilità della cosa (availability of the thing) by Stefano Arienti and Cesare Pietroiusti.

The decision to dedicate an in-depth study to the MAMbo was dictated by the museum's very precise features. Differently from other institutions usually oriented towards the internationalisation of their collections and exhibitions, the MAMbo is very closely linked to the history of Bologna and involved in the production of relational and participatory projects that dialogue with it and deconstruct the system of museum relations. With the aim of becoming a platform for and a reflection of the Italian art scene, ever since it was first opened ${ }^{22}$, the museum has had the privileged objective of creating a centre of creativity and a meeting point between artists and citizens, providing wide ranging didactical services. The interest in relational, co-authored and participatory projects has led the museum to promote and produce works focussed on the topic of art law, and to organise conferences and meetings. Law therefore becomes the key to approaching and interpreting the work, used on an international level to mediate it via a known and

21 The same operation was initiated at the museum in Düsseldorf, the Kunstsammlung Nordrhein-Westfalen (K21) with the work Das Deutschlandgerat (1990): originally designed for the German Pavilion at the Venice Biennale, this imposing installation was acquired by the German museum and displayed in 2002 in the large spaces of the museum's ground floor. Cf. LOOCK, Ulrich. "Can a contemporary art museum support the anachronism of a work which fundamentally challenges the museum's historic mission?”. Cura Magazine. vol.1, no. 3, 2010, pp. 58-62.

22 Created in 2007 from the Galleria of Modern Art of Bologna, the MAMbo is one of the oldest civic galleries in Italy and at the same time also one of the most recently restructured. 
recognised channel. Public participation in the process of conceiving and producing artistic activities and operations has become a specific objective of the MAMbo, via the promotion of special projects with various levels of interactivity. The museum puts itself forward, not only as an intermediary or activator of pedagogical projects and processes, but also as a legal entity, a recognised part of the relationship.

Our case study is the exhibition project, completely unprecedented for a museum, entitled Nine projects for Pavillion de l'Esprit Nouveau, conceived by the British conceptual artist Ryan Gander based on the history of the Padiglione de l'Esprit Nouveau by Le Corbusier: built on the occasion of the international Exhibition of modern decorative and industrial arts in 1925 and destroyed in May 1926, the exhibition building was rebuilt in 1977 by Josè Oubrerie and Giuliano Gresleri in the trade fair area of Bologna. The exhibition, mounted in 2006, intended to create a time bridge between 1925, 1977, 2006 and 2056 using a kind of elaborate time machine that included nine interventions ${ }^{23}$. To achieve this, Gander worked out a plan comprised of a series of objects and conceptual operations that created numerous references to the history of modern architecture. These were comprised of interventions designed by the artist but carried out, under detailed instructions, by the museum staff and other figures connected to it. Whilst the first seven interventions were more closely linked to the extemporaneous event of the exhibition, with Time capsule Gander pushed even further, legally binding the MAMbo to the work's destiny, as its guarantor, executor and future owner. This last project is a device activated in 2006 and programmed to give rise to a physical object in 2056. At the time of its conception the work consisted of a legal document, a series of instructions and a sum of money deposited in a bank account, operations required to conclude the project in 2056 with the completion of the ninth step entitled New adventures in... (fifty years later), new curtains for Pavilion de l'Esprit Nouveau. Following the instructions provided in the legal document, the museum will have to carry out a series of actions and delegate others to a special performer: it will have to trace one or more children belonging to the genealogical tree of Le Corbusier and Yvonne Gallis, identify and produce determined colours-which correspond with the original combinations used inside the pavilion-and send them to the performers/children. The children will then make a drawing that will become the basis of a pattern for a set of curtains, which will then be prepared and installed in the large window of the Esprit Nouveau Pavilion.

On the occasion of the exhibition in 2006, the museum staff began executing the artist's idea, drawing up a legal contract and depositing the necessary sum in a bank account and researching the architect's genealogical tree in order to find potential great grandchildren as well as the palette of original colours used on the pavilion. Photographic documentation of this process was the basis of the installation displayed in the pavilion in 2006: of eighty slides projected onto a screen, forty were documentary photographs of stages of the creative and production process, whist the remaining forty documented research into the range of colours for the interior walls. The installation also included an exhibition of the Trustee time capsule, the legal instrument identified as being the most suitable for protecting the relationship between museum and artist ${ }^{24}$. According to Gander's idea, the Trustee should have been the museum or one of its staff: however, the public nature of the institution prevented this procedure, delegating the role to the curator. The legal document signed by curator and artist, in the presence of an interpreter, two witnesses and a notary, stated that: the Time capsule project, designed to create an end product entitled (Fifty years later), new adventures in... new curtains for Pavilion de l'Esprit Nouveau to be created and displayed in 50 years time in
23 Cfr. VILLANI, Andrea. Ryan Gander, Nove progetti per il Padiglione de l'Esprit Nouveau. Bologna: MAMbo 2006.
24 A Trust is a legal instrument that allows one or more people to transfer the title of one or more properties to one or more Trustees. 
the Esprit Nouveau Pavilion by the City of Bologna, was entrusted to the curator ${ }^{25}$. The Time capsule trust thus defined, set out that the end product should be installed, as a gift to the museum and the City of Bologna, in the pavilion to benefit present and future generations, protecting, during this timeframe, the instructions and the sum of money for its creation. With regards to author's rights, the document recognises that the moral rights to the project belong to the artist and the rights to the end product to the descendants of Le Corbusier, who will have to renounce their rights to financial gain. If the descendants accept these conditions and the whole process reaches its conclusion, the end product will belong to the City of Bologna, for as long as it benefits its citizens. The museum will therefore become the owner of the work only if it ensures all the conditions are met: in the first place that the trustee, the curator, allows "the New Trustee to exercise the rights owing to the Assets of the Trust". This transfer has not yet been made and changes in the curatorial and management staff of the museum have influenced, and will continue to influence, the operation's outcome. The time capsule is for now only guaranteed by the employee that coordinated the entire project. If this memory is lost, and with it interest in the project, the museum will miss out on a work destined for the public. In its complexity, the work activates a series of reflections on the art museum system, which involves different actors and considers multiple external conditionings. The practice of changing figures at the top of the museum staff, means that the director and curator, which despite being aware and responsible promoters of certain projects, cannot guarantee permanence in their given roles up to the completion of the same. The maximum responsibility is consequently delegated to stable employees responsible for maintenance and documentation. These employees thus assume a key role as witnesses of the institution's activities and experiences, including participatory and relational projects that require long-term commitment. The artist assumes a new and complex role, starting out from an idea, he activates a process via detailed instructions and contracts that form the basis of the legitimacy of his operation, delegating the execution to third parties. Lastly there is the involvement of co-authors, whose moral rights must be respected. Time capsule also reflects on the distance separating an idea and its future execution, on the public museum's need for an end product, and lastly on the importance of contractual documentation in defining the people involved. This, in a time when confusion surrounding authorship between curators, conservators and artists and between work, document and instructions, leads to the loss or disownment of many contemporary works.

Two years after the Gander experience, the Bologna museum launched itself into another relational project entitled Disponibilità della Cosa. This also involved author's rights, lawyers, a contract, co-authorship and an end product. If in Time capsule there were only a few subjects involved in the legal process, selected by the artist based on their social and professional positions or parentage, here the relationship was open to all those wishing to take part, whether private citizens or museum staff. Disponibilità della Cosa (2008-2012) is the result of complex relationships activated between several figures: two artists, Stefano Arienti and Cesare Pietroiusti, engaged in their respective creative processes, a contemporary art law solicitor, Paolo Bergmann; the MAMbo in Bologna and its visitors and staff. Stefano Arienti and Cesare Pietroiusti were invited to conceive an exhibition during the opening of SPAZIOGAM, a project conceived and organised by the MAMbo on the initiative of the museum director and registrar, with the intention to open the museum to different types of use, reflecting on the works in the collection, on the role of the museum as a place for research, the exchange of ideas and communication, and on the history and cultural tradition of Bologna. The result, entitled Regali e Regole. Prendere, dare, sbirciare nel museo, took the form of a container of different 
experiences—an exhibition, a relational and participatory project, a round table and a workshop-that investigated behind the scenes at the museum, creating relationships between worlds that are usually divided, those of staff, artist and public. The relational process activated by the exhibition started with 2000 drawings to take, an interactive installation of drawings on a wall—which the public could take freely — made in part by the artists and in part by a group of students from the Accademia di Belle Arti in Bologna, asked to participate in the conception, production and display of the exhibition by the educational department. The artists therefore involved other figures not only in the material creation of the drawings but also in the conception and development of the idea, fully recognising their role as co-authors. As part of the exhibition, small sound and image recording devices allowed visitors to peep behind the scenes and access areas of the museum dedicated to organisation and management, otherwise not visible to the public. The museum thus expanded its boundaries, becoming transparent and sensitive to the variability of the artistic operation it actively participated in as guarantor, custodian and collaborator. In the third project presented as part of Disponibilità della Cosa, the challenge to the role of the museum and the art system is brought to its conclusion.

The project involved the construction of a system of relations without precise spatial or temporal limits, based on an exchange between the public and the artist. The project's aim was to create a sculpture of variable dimensions made of 50 euro banknotes, which once considered finished would be sent to auction. By giving the artists a 50 euro banknote in good condition, each visitor was able to participate in the project. In return they were asked to sign a contract and given a numbered certificate authenticated by the artists, binding them to the work's financial and material destiny. The banknotes were manipulated during a public performance by Arienti. The difference between the financial value of the work, corresponding with the sum total of the banknotes, and the auction sale price of the work, according to the artists would define the artistic and authorial value of the operation. The sale price achieved by the work would then be divided between the participants as a proportional share of the purchase surplus value, only when the contribution certificates were returned to the artists. Participants were free to collect their banknote at any time in exchange for the certificate or to keep the signed and authenticated multiple/ certificate instead of receiving the envisaged amount, in order to display it at home or sell it, putting it back into the marketplace in this way. The project lasted four years and concluded in 2012, when the piece, composed of a total of 202 banknotes, went unsold at auction at Sotheby's in Milan. Following this, the artists and museum began the 'de-installation' process, returning the banknotes in exchange for the contribution certificates. Any unreturned contribution certificates purchased via valid contract were left in the owners' hands, and thereby in the marketplace, retaining their value as signed and numbered artists' multiples.

This project aimed to undermine the logic behind the art market, based on the idea that a work of art is not only a product that can be sold at a given price, but also an asset that can generate financial profit. The artists' intention was to follow the behaviour and destiny of the piece in all its unpredictability. If the work had not remained unsold, the museum, the artists and the contributors would still be engaged in the observation of this unpredictability as part of the display, conservation and documentation of the piece. It is therefore the relationships created between these figures that constitute the work's consistency and identity. Each "non-human actor" gives rise to relationships, subjects, processes of exchange, transactions and dispositions that call the law into question. The fundamental component of the artistic operation is the relationship between multiple subjects participating in the exchange: the artists (authors), the lawyer (consultant), the visitors (co-participants) and the museum staff (museum). If the conceptual phase is entrusted entirely to the artists, the lawyer and in part the museum, the production stage is shared between several participants: participating in the financial exploitation of the work, they are involved in all stages of its development, 
from production to promotion, conservation and documentation, up to the sale and "de-installation" of the work, as well as in the future re-conversion of its physical consistency into other forms.

If as in the case of Gander, the two artists retained the copyright to the project, remaining its authors, the project could not have been realised without the professionalism and competence of the lawyer. There are also many ghost figures in the art world-mostly falling under the headings of consultancy, execution or production. The moment a visitor enters the museum and signs a contract for the creation and expansion of the work, he becomes an underwriter and co-owner as well as a sponsor, collector and co-participant in the work's financial destiny. This is achieved via a pact of co-participation in any profit gained from the operation signed with the two artists. The museum is the custodian of the work and guarantor of its development, promotion and visibility, as well as its conservation and documentation. As with many other relational and participatory projects culminating in the creation of a physical and material object, a construction everyone has taken part in, the physical consistency of the work is not the end product but rather the medium of activation of a process. The museum chose to document the project not via a paper catalogue, but via a support that could effectively adapt to its temporality, randomness and performative nature: a double DVD gathering together audio interviews, texts, documents and recordings of events and participants, providing a visual record of the relations that were created between the various figures ${ }^{26}$. If Disponibilità della Cosa officially concluded in 2012, the 'cosa/thing' lives on in the documentary evidence and contribution certificates establishing the material 'artistic value'.

\section{Conclusions}

The cases we have examined present three methods of creation by artists proposing, via conceptual work, different ways of conceiving an artwork as an activator for a cognitive device able to investigate the mechanisms of the museum system and art system through different levels of co-participation. In the case of Mucha, via the activation of an imposing production system, in the case of Gander, Arienti and Pietroiusti, via the involvement of all actors, including museum visitors, in a relationship also expressed on a legal level. What emerges from this analysis is that mediation between artist-public-museum and the work depends on the mingling of several factors: the identity of the artistic operation, the properties of the museum and its will to take part in the creative process and lastly, the relationship activated between artist-museum-public. If as recent studies based on the Actor Network and Complex System Theories confirm, the identity of the work depends on the observer and on practices and actions that have produced and presented it each time, the fact that artists often use museums not only as a place for meetings and mediation with the public, but also as an active interlocutor cannot be left aside. The artist, the first actor in the scene, is called by the museum and enters it, with his artistic operation, to cooperate with the formulation of approaches to the exhibition, documentation and conservation of the work, disrupting and decomposing its system like a researcher disassembles and investigates their area of research, calling many different actors to their aid. Despite their diversities, these three case studies lead to the presentation of the museum as a platform aiming to investigate the activation of creative processes, thanks to and in collaboration with the artist, using its own "behind the scenes" and in this way creating a system in which the collaborative aspect of management practices reflects that of the artist's research. 


\section{Bibliography}

ARIENTI, Stefano, et al. Regali e regole. Prendere, dare, sbirciare nel museo. Bologna: edizioni Comune di Bologna - Istituzione Galleria d'Arte Moderna, 2010.

BECKER, Howard. Les Mondes de l'art, Paris: Flammarion, 1988.

BISHOP, Claire. Installation Art: A Critical History. London: Tate Publisher, 2005.

BISHOP, Claire. Artificial Hells. Participatory Art and the Politics of Spectatorship. London: Verso, 2012.

BOURRIAUD, Nicolas. Estétique Rélationelle, Paris: Presses du réel, 1998.

BRINCK, Ingar. "Situated Cognition, Dynamic Systems, and Art: On Artistic Creativity and Aesthetic Experience". Janus Head: Journal of Interdisciplinary
Studies in Literature, Continental Philosophy, Phenomenological Psychology, and the Arts. vol. 9, no. 2, 2007, pp. 407-431.

BURNHAM, Jack. "Systems Esthetics”, Artforum. vol. 7, no. 1, September 1968.

COULTER-SMITH, Graham. Deconstructing Installation art. 'www.installationart.net/' (retrieved in September 2014).

IRVIN, Sherri. "Museums and the Shaping of Contemporary Artworks". Museum Management and Curatorship. vol. 21, no. 2, 2006, pp. 143-156.

LATOUR, Bruno. Reassembling the social. An introduction to Actor-Network-Theory. Oxford: Oxford University Press, 2005.

LOOCK, Ulrich. "Can a contemporary art museum support the anachronism of a work which fundamentally challenges the museum's historic mission?”. Cura Magazine. vol.1, no. 3, 2010, pp. 58-62.
MENSCH, Léontine Meijer-van, TIETMEYER, Elisabeth. Participative Strategies in Collecting the Present. Berlin: Panorama Verlag, 2013.

NOORDERGRAAF, Julia, et al. Preserving and exhibiting Media Art. Challenges and Perspectives. Amsterdam: Amsterdam University Press, 2013.

REISS, Julie H. From Margin to Center: The Spaces of Installation Art. Cambridge: MIT Press, 1999.

SAAZE, Vivian van. Installation Art and the Museum. Presentation and Conservation of Changing Artworks. Amsterdam: Amsterdam University Press, 2013.

VILLANI, Andrea. Ryan Gander, Nove progetti per il Padiglione de l'Esprit Nouveau, Bologna: MAMbo 2006.

YANEVA, Albena. "When a bus met a museum: following artists, curators and workers in art installation”. Museum and Society. vol. 1, no. 3, 2003, pp. 116-131. 


\section{Le musée d'art contemporain: un espace-temps pour la participation créative et la production d'œuvres d'art complexes. Quelques cas de la scène italienne}

Les pratiques de gestion et d'installation dans les musées ont transformé les œuvres de création artistique contemporaine en systèmes relationnels et lieux de création collective du patrimoine. La plupart des œuvres présentées dans ces espaces sont des hybrides complexes, variables et relationnels, des activateurs de recherche, d'expérience, de créativité, de sensations, de relations et de connexions. En outre, le désir de s'ouvrir vers des perspectives inhabituelles par le biais du processus de recherche-création mène souvent les artistes à se tourner vers d'autres professionnels, tels que physiciens, chimistes, juristes, sociologues ou anthropologues, afin qu'ils interagissent avec leurs œuvres. De façon à faire face aux défis que pose cette production variable et complexe en termes de conservation, d'exposition et de documentation, le musée a adopté une structure diversifiée. Au sein de cette structure et par l'entremise de pratiques d'installation et d'exposition et de techniques curatoriales précises, les expositions deviennent des moments de cocréation, d'échanges, de conscientisation et d'idéation qui lèvent le voile sur le réseau intriqué de relations qui existent au sein du musée. À l'aide de cas d'études - un projet artistique pédagogique participatif, une œuvre relationnelle et une installation in situ - issus de deux musées d'art contemporain italiens, le Musée d'art moderne de Bologne (MAMbo) et le Castello di Rivoli, l'article présente trois méthodes de recherche-création proposées par des artistes. Celles-ci, par le biais d'une démarche conceptuelle en tant qu'activateur d'un dispositif cognitif, parviennent à sonder les mécanismes de la structure muséale et du système de l'art grâce à divers niveaux de coparticipation et d'" auteurité collaborative ". Il émerge de cette analyse que la médiation entre artiste-public-musée et œuvre dépend de la combinaison de plusieurs facteurs : la nature de l'opération artistique, les biens du musée et sa volonté de prendre part à la recherche-création, et enfin la relation développée entre l'artiste, le musée et le public. L'artiste est appelé par le musée (et s'y introduit avec son processus artistique) à collaborer à la formulation des approches d'exposition, de documentation et de conservation des œuvres, en perturbant et décomposant son système de la même façon qu'un chercheur démonte et approfondit son champ de recherche, en faisant appel à diverses sources. En dépit de leur diversité, ces études de cas mènent à la représentation du musée en tant que plateforme qui cherche à investiguer l'activation de la recherche-création, grâce à l'artiste et en collaboration avec lui, en faisant usage de ses propres coulisses et en créant un système au sein duquel l'aspect collaboratif des pratiques de gestion reflète celles de la recherche-création de l'artiste. 